\title{
Eksperter i valgkamp: Proces eller indhold?
}

\section{AF ERIK ALBAK, CHRISTIAN ELMELUND-PRASTEKAR, DAVID NICOLAS HOPMANN \& ROBERT KLEMMENSEN}

Brugen af eksperter i den danske presse er eksploderet i de sidste årtier. I denne artikel undersøges, hvordan journalisterne bruger eksperter i valgkampe. To folketingsvalgkampe bliver analyseret: 1998 og 2007. I absolutte tal findes en stigning i de fire aviser, vi undersøger, men der er forskelle mellem bladene. Desuden finder $v i$, at omfanget af dækningen af valgkampen er faldet voldsomt. Derimod finder vi ingen forandring i henhold til, hvor meget fokus der er på den politiske proces kontra politiske forslag og emner.

Er det tilfældigt, at Danmark har fået et aktualitetsprogram med navnet ,Jersild og spin?“ Et program, der analyserer og diskuterer politiske aktørers strategier for og motiver til at foretage sig eller udtale dette og hint? Et program, i hvilket det mest opsigtsvækkende, der ville kunne siges om en politikers handlingsmotiver, er: „Jeg tror faktisk, hun mener det!“1

Ifølge den internationale journalistiskforskning: Nej, det er ingen tilfældighed. At der i journalistikken i dag i højere grad end tidligere fokuseres på den politiske proces frem for politikkens indhold, er den foreløbige kulmination på en lang udvikling (f.eks. Patterson 1994). I partipressens tid havde politikerne adgang til uformidlet og direkte at kommunikere deres budskaber til relevante vælgergrupper. Med omnibuspressens fremvækst mistede politikerne dette direkte talerør. Deres budskab havde ikke længere automatisk nyhedsværdi, men måtte tilfredsstille 
de generelle, professionelle nyhedskriterier, som blev udviklet for at fange nyhedsformidlernes opmærksomhed. Kriterier, som tildelte journalister en betydelig mere fremtrædende og aktiv rolle som nyhedsvogtere (gate-keepers), dvs. som dem, der på læsernes, lytternes eller seernes vegne vurderer, om et politisk budskab har tilstrækkelig nyhedsværdi til at fortjene formidling via nyhedsmedierne.

Politiske aktører mødte ikke længere mikrofonholdere, men professionelle journalister, der kritisk granskede deres forslag, handlinger og udsagn. De oplevede, at de konstant skulle forsvare sig. Og at de handlede reaktivt i forhold til en dagsorden, som blev sat af andre end dem selv. I et forsøg på at tilbageerobre kontrollen med kommunikationen og blive mere proaktive begyndte de politiske aktører at professionalisere deres kommunikation ved at hyre kommunikationseksperter og journalister med forstand på mediernes måde at fungere på.

Men kampen om kontrollen over den politiske kommunikation fortsatte. Journalisterne så de politiske aktørers professionaliseringen som udtryk for markedsføring og manipulation. Journalister er afhængige af politiske aktører som kilder til deres nyhedsdækning. Men når de kun kan nå de politiske aktører gennem et professionelt kommunikationsfilter, får de sværere og sværere ved at vurdere den vare, som politikerne forsøger at sælge. Det svarer til at være afhængig af tandpastaproducentens marketingsafdeling, når man som journalist kritisk skal bedømme, om tænderne virkelig bliver så hvide, som reklamen lover.

Derfor blev det for journalister nødvendigt at give borgerne forbrugeroplysning: At analysere og skildre, hvordan politik gennem professionel markedsføring bliver forsøgt solgt til vælgerne. Det har ført til, at den politiske journalistik i stigende grad fokuserer på den politiske proces. Det sker dels ved, at den politiske proces analyseres og skildres som et strategisk spil mellem egennyttemaksimerende politiske aktører; dels ved, at den politiske journalistik retter blikket mod sig selv og analyserer, hvordan den forsøges manipuleret af andre aktører (det, der er blevet kaldt meta-nyhedsdækning). Med andre ord: Der fokuseres i stigende grad på journalistik og spin.

Denne udvikling er forskningsmæssigt veldokumenteret i ud- 
landet, især USA, men også Storbritannien og Tyskland (Esser \& D’Angelo 2006; Esser et al. 2001). Men hvad med Danmark? Her findes ikke samme forskningsmæssige dokumentation for udviklingen i den politiske journalistik (se dog Bro et al. 2005 for et „øjebliksbillede“ af 2005-valgkampen). Umiddelbart virker der dog til at være noget om snakken. Vi har ikke kun „Jersild og spin“. Vi ser mange andre eksempler på, at fokus er rettet på den politiske proces. Som når dagbladenes kommentatorer gang på gang optræder som eksperter i de elektroniske medier: Berlingske Tidendes Thomas Larsen, Jyllands-Postens Ralf Pittelkow, Politikens Peter Mogensen, BT's Helle Ib og Ekstra Bladets Hans Engell - for nu at nævne de mest kendte. Hertil skal så lægges Se og Hørs Henrik Qvortrup. De udlægger teksten, fortolker politikernes handlingsmotiver, kortlægger deres mulige strategier.

En anden indikator på det øgede procesfokus i dansk journalistik er den blotte forekomst af ordet „spindoktor“. En søgning på InfoMedia ${ }^{2}$ viser, at ordet i perioden 1 . januar 1990 til 31. december 1999 blev benyttet i 7 artikler, hvoraf de fleste omhandlede USA og England. I perioden 1. januar 2000 til 31. december 2007 indgik ordet i 2.403 artikler (i de samme aviser).

At kortlægge udviklingen i den politiske journalistiks procesfokus i Danmark vil kræve en omfattende forskningsindsats. Det har ikke været muligt i nærværende sammenhæng. Derimod har det været muligt at kortlægge en afgrænset del af problemstillingen, nemlig udviklingen i dagbladenes brug af eksperter i valgkampsdækningen.

Hvor det i de elektroniske medier synes åbenlyst (men fortsat ikke forskningsmæssigt dokumenteret), at der i stigende grad hentes eksperter ind til at kommentere den politiske proces i forbindelse med valgkampe (ikke mindst ovennævnte dagbladskommentatorer), hvordan ser det så ud i de trykte medier?

De trykte mediers brug af eksperter er generelt steget eksplosivt i de seneste par årtier (Albæk et al. 2002). Ser man alene på brugen af forskere, som udgør en væsentlig delmængde af de eksperter, som der refereres til, er der i perioden 1961-2001 sket en syvdobling i antallet af nyhedsartikler i danske aviser, hvori der henvises til forskere. Stigningen hænger sammen med to andre udviklingstræk: Det ene er, at dagspressen i relativt mindre grad 
end tidligere bruger forskere som formidlere af egen og andre forskeres viden. I stedet benytter pressen i stigende grad forskere til at kommentere på politiske problemer og andre forhold, hvor dagsordenen sættes andre steder end i forskernes elfenbenstårn.

Det andet udviklingstræk er, at pressen ikke længere hovedsagelig citerer repræsentanter for de "hårde“ videnskaber, men i stedet samfundsforskerne. Det er dem, der flittigst kommenterer på små og store problemer, som genereres uden for universiteterne - de seneste vælgerundersøgelser eller justitsministerens seneste udspil til en revision af strafferammerne for en given forbrydelse.

Når der er sket en så voldsom stigning i avisernes brug af eksperter i den generelle nyhedsjournalistik, er det nærliggende at forestille sig, at dagbladsjournalister også trækker på eksperterne i en valgkamp - på samme måde som deres kolleger i de elektroniske medier øjensynligt gør det. Eksempelvis som da flere aviser i den seneste valgkamp som noget nyt lavede deciderede „faktatjek" af de påstande, som blev fremsat af de politiske partier. Her ville det være oplagt for avisernes journalister at henvende sig til eksperter for at få en vurdering af, hvad der er fakta, og hvad der er måske ikke direkte fup, så i al fald mindre faktuelt korrekt. Men journalister kan også trække på eksperter til at vurdere valgkampsprocessen - eksempelvis kunne en journalist bede en valgforsker om en vurdering af mulige årsager til udsving i meningsmålingerne eller de politiske partiers motiver til at komme med et bestemt forslag.

Artiklen forsøger på denne baggrund at besvare to overordnede spørgsmål: Hvordan bruger dagbladenes journalister eksperter i en valgkamp? Har der været en udvikling i denne brug over de seneste ti år?

\section{Datagrundlag}

I de fire aviser Politiken, Berlingske Tidende, Jyllands-Posten og Ekstra Bladet er alle valgkampsrelaterede nyhedsartikler blevet registreret i perioderne 20. februar-11. marts 1998 og 25. oktober13. november 2007, dvs. fra den dag, valget blev udskrevet det pågældende år, og til og med valgdagen. I begge år var der nøjagtig 
21 dages valgkamp, når dagene for valgets udskrivelse og afholdelse medtages. Det betyder, at der ikke skal korrigeres for valgkampens længde i de beregninger, der foretages.

De artikler, i hvilke der henvises til eksperter, er blevet gennemlæst og kodet for en række forhold. Det benyttes et bredt ekspertbegreb: Alle, der tillægges en ekspertrolle i en nyhedsartikel, dvs. optræder som en person med særlig viden på et givet felt. Det inkluderer eksempelvis en modeekspert, der kommenterer kvindelige politikeres påklædning. En artikel er medtaget, hvis en ekspert citeres, eller hvis der på anden vis refereres til eksperten (eksempelvis Henrik Qvortrups kontrovers med Naser Khader under valgkampen i 2007) eller dennes produkter (videnskabelige rapporter eller lign.).

Fraregnet analysen er i første omgang artikler forfattet af avisens egne journalister eller kommentatorer, hvor disse kan siges at optræde som ekspert. Derimod er artikler medregnet, når en avis' kommentatorer eller journalister optræder som ekspert i en artikel, de ikke selv står som forfatter til - i deres egen eller andre aviser.

Ved 2007 valget er artikler forfattet af én kommentator for hver af de fire aviser, der samtidig ofte optrådte som ekspert i de elektroniske medier under valgkampen, dog kodet på samme måde som øvrige ekspertartikler. ${ }^{3}$ Disse artikler indgår ikke som en del af ekspertartiklerne i 2007, men kodningen giver en mulighed for at sammenligne artikler forfattet af politiske kommentatorer med almindelige journalistiske artikler, hvori der optræder eksperter.

Kodningsenheden er den enkelte artikel. Artiklerne er blevet registreret på følgende parametre: (1) Hvad handler artiklen om; indhold (nævnes et eller flere politiske emner og i givet fald hvilke(t)?) eller proces (omtales partiernes strategi, politikernes personlighed, mediernes behandling af valgkampen, eller hvordan partierne står i forhold til hinanden, herunder i meningsmålinger?). (2) Nævnes der politiske partier eller kombinationer af partier (regering, opposition mv.). Hvis en artikel omhandler både et politisk indhold og den politiske proces, er artiklen kodet i begge kategorier. (3) Hvilken type ekspert refereres der til i artiklen. 
Kodningen er foretaget af tre kodere. Der er for alle variabler en interkoderrealibilitet på over o.8.

\section{Hvor mange artikler og eksperter?}

Der er sket et bemærkelsesværdigt samlet fald i antallet af valgkampsartikler i den analyserede periode, fra 1.163 i 1998 til 862 i 2007 (se tabel 1), dvs. en samlet reduktion i antallet af valgkampsartikler på hele 26 procent over den analyserede niårige periode.

Faldet hænger givetvis sammen med netavisernes vækst. Stadig flere nyheder bringes som netop en nyhed i avisernes netudgave, men trykkes ikke i morgendagens papirudgave, eftersom den da ikke længere er nogen nyhed. Eksempelvis bringer Politiken i dag de vigtigste af gårsdagens netnyheder i et overbliksbånd øverst i første sektion af den trykte avis, mens resten udelades. Det har alt i alt betydet en reduktion i antallet af nyhedsartikler i den trykte avis og en relativ opprioritering af baggrunds-, analyse og opinionstoffet (se Politiken 1. oktober 2006). Berlingske Tidende har (endnu) ikke foretaget en tilsvarende tilpasning, hvilket formentlig kan forklare, at avisen har oplevet en stigning i antallet af valgkampsartikler fra 243 til 273, mens de tre øvrige aviser har oplevet markante fald i antallet - Politiken fra 321 til 173, Jyllands-Posten fra 426 til 289 og Ekstra Bladet fra 173 til 127.

Man kunne have forestillet sig, at den relative opprioritering af

\section{Tabel 1}

Valgkampsartikler (antal) og andel med eksperthenvisning, 1998 og 2007

\begin{tabular}{lcc|cc}
\hline & \multicolumn{2}{c|}{1998} & \multicolumn{2}{c}{2007} \\
\hline $\begin{array}{l}\text { Valgkamps- } \\
\text { artikler }\end{array}$ & $\begin{array}{c}\text { Andel med } \\
\text { eksperter }\end{array}$ & $\begin{array}{c}\text { Valgkamps- } \\
\text { artikler }\end{array}$ & $\begin{array}{c}\text { Andel med } \\
\text { eksperter }\end{array}$ \\
\hline Politiken & 321 & 8 & 173 & 11 \\
\hline Jyllands-Posten & 426 & 5 & 289 & 22 \\
\hline Berlingske Tidende & 243 & 10 & 273 & 14 \\
\hline Ekstra Bladet & 173 & 6 & 127 & 1 \\
\hline I alt & 1163 & 7 & 862 & 14 \\
\hline
\end{tabular}


Tabel 2

Ekspertartiklers størrelse. Antal ord, gennemsnit

\begin{tabular}{lcccc}
\hline & Politiken & $\begin{array}{c}\text { Jyllands- } \\
\text { Posten }\end{array}$ & $\begin{array}{c}\text { Berlingske } \\
\text { Tidende }\end{array}$ & Ekstra Bladet \\
\hline 1998 & 770 & 651 & 897 & 578 \\
\hline 2007 & 598 & 550 & 704 & 452 \\
\hline
\end{tabular}

Tabel 3

Valgkampsartikler med eksperthenvisning, 1998 og 2007. Antal

\begin{tabular}{|c|c|c|c|c|c|}
\hline & Politiken & $\begin{array}{l}\text { Jyllands- } \\
\text { Posten }\end{array}$ & $\begin{array}{c}\text { Berlingske } \\
\text { Tidende }\end{array}$ & $\begin{array}{l}\text { Ekstra } \\
\text { Bladet }\end{array}$ & I alt \\
\hline \multicolumn{6}{|c|}{1998} \\
\hline 1 & 17 & 14 & 17 & 7 & \\
\hline 2 & 7 & 4 & 5 & 2 & \\
\hline$>=3$ & 1 & 3 & 3 & 2 & \\
\hline I alt & 25 & 21 & 25 & 11 & 82 \\
\hline \multicolumn{6}{|c|}{2007} \\
\hline 1 & 13 & 40 & 24 & 1 & \\
\hline 2 & 3 & 16 & 6 & & \\
\hline$>=3$ & 3 & 8 & 8 & & \\
\hline I alt & 19 & 64 & 38 & 1 & 122 \\
\hline
\end{tabular}

opinions-, baggrunds- og analysestoffet hos Politiken ville have øget den enkelte artikels længde, ikke mindst fordi avisen ved lanceringen af det nye format blev kritiseret for avisens relativt mange, rigtig lange artikler. Men som det fremgår af tabel 2, holder det ikke stik, i hvert fald ikke når det drejer sig om valgkampsartikler med eksperthenvisninger: Både Politikens, Jyllands-Postens og Ekstra Bladets artikler var næsten en fjerdedel kortere i 2007 end 1998. Berlingske Tidendes artikler blev kun 15 procent kortere, og Berlingske er fortsat den avis, der har de længste valgkampsartikler med ekspertreferencer.

Der optræder generelt meget få eksperter i valgkampsartiklerne i de fire analyserede aviser. Og kun få af disse artikler, 24 tilsammen i 1998 og 2007, er forfattet af eksperten selv. Som det 
fremgår af tabel 3, er der i både 1998 og 2007 i mere end to tredjedele af artiklerne kun henvisning til en enkelt ekspert, i 22 procent af artiklerne til to. Journalisten kan selvsagt have kontaktet flere eksperter for at indsamle baggrundsmateriale, men i artiklens dramaturgi optræder som regel kun en enkelt og i nogle tilfælde to eksperter.

Det fremgår også af tabellen, at der i perioden 1998 til 2007 er sket en stigning i det samlede antal valgkampsartikler, der henviser til eksperter fra 82 til 122. Tallene dækker dog over betydelige variationer aviserne imellem. I 1998 refereredes der cirka lige ofte til eksperter i de tre morgenaviser. Men med en stigning fra 21 artikler i 1998 til hele 64 i 2007 adskiller Jyllands-Posten sig markant fra Berlingske Tidende med en stigning fra 25 til 38 ekspertartikler i perioden og Politiken med et fald fra 25 til 19.

Ekstra Bladet adskiller sig fra de tre morgenaviser på to måder: For det første er antallet af valgkampsartikler generelt og antallet af valgkampsartikler med henvisning til eksperter i Ekstra Bladet betydelig mindre end i de tre morgenaviser i både 1998 og 2007. For det andet er der sket et markant fald i antallet af valgkampsartikler med henvisning til eksperter. Der var 11 artikler i 1998 men kun en enkelt i 2007. Ser man dog på indholdet i Ekstra Bladets artikler, kan faldet synes mindre end ved første øjesyn: I 1998 var formålet med at henvise til eksperter i fem af artiklerne, altså tæt ved halvdelen, ikke substantielt at belyse valgkampen, men eksplicit at gøre grin med valgforskere.

Når antallet af artikler om valgkamp generelt er faldet, bliver det interessant også at se på den relative andel af valgkampsartikler med eksperter. Som det fremgår af tabel 3 er der for de fire aviser samlet set sket en stigning fra 7 procent i 1998 til 14 procent i 2007. Mest markant hos Jyllands-Posten med en stigning fra 5 til 22 procent; Politiken har oplevet en svag stigning fra 8 til 11 procent, det samme har Berlingske Tidende fra 10 til 14 procent, mens faldet er markant hos Ekstra Bladet fra 6 til én procent. I sidstnævnte tilfælde bør man dog have in mente, at de absolutte tal er meget små. 


\section{Hvem er eksperterne?}

Af tabel 4 fremgår, at forskere optræder langt hyppigere som eksperter i valgkampsartikler end de øvrige ekspertgrupper tilsammen, nemlig i tæt ved to tredjedele af tilfældene - med relativt lidt færre forskere i Jyllands-Posten end i Politiken og Berlingske Tidende og markant færre i Ekstra Bladet (for en lignende konklusion se Bro et al. 2005; Journalisten 19.11.2007). Når man ser på de øvrige ekspertgrupper, er to ting værd at bemærke.

For det første er det en udbredt opfattelse, at de politiske kommentatorer fylder mere i mediebilledet end tidligere. Det er imidlertid ikke tilfældet: I de fire undersøgte aviser er der meget få henvisninger til kommentatorer (artikler skrevet af avisernes egne kommentatorer er ikke medtaget i tabellen). Og en del af henvisningerne i 2007 handler i øvrigt om den konflikt, der opstod mellem Nasser Khader og Se og Hørs dav. chefredaktør, Henrik Qvortrup, der som tidligere spindoktor for Anders Fogh Rasmussen ofte optræder i de elektroniske medier som ekspert. Artiklerne omhandler med andre ord en metadiskussion dels om selve konflikten mellem Khader og Qvortrup, dels om DR og TV2 kunne benytte Qvortrup som kommentator i den resterende del af valgkampen, når han var blevet en del af den.

Det er muligt, at de politiske kommentatorer fylder mere i de elektroniske medier, hvor man af dramaturgiske grunde har behov for at få en politisk analyse frem som en dialog mellem stu-

\section{Tabel 4}

Ekspertartikler fordelt på eksperttype, 1998 og 2007 under ét. Antal

\begin{tabular}{lcccc}
\hline & Politiken & $\begin{array}{c}\text { Jyllands- } \\
\text { Posten }\end{array}$ & $\begin{array}{c}\text { Berlingske } \\
\text { Tidende }\end{array}$ & Ekstra Bladet \\
\hline Forsker & 30 & 44 & 46 & 4 \\
\hline Kommentator & 3 & 5 & 6 & 0 \\
\hline Bankansat & 0 & 2 & 3 & 0 \\
\hline Offentlig ansat & 2 & 7 & 1 & 1 \\
\hline Tænketank & 1 & 6 & 0 & 0 \\
\hline Andet & 7 & 19 & 5 & 6 \\
\hline
\end{tabular}


dievært og ekspert. De elektroniske medier kan ikke lade deres egen huskommentator, som eksempelvis DR's Ask Rostrup, analysere dagens begivenheder i monolog på samme måde, som de trykte avisers huskommentatorer kan skive en klumme. Der må som minimum foretages et interview med vedkommende, i tvstudiet eller andetsteds. Men i længden vil det blive problematisk at vise mediets egen kommentator om og om igen på skærmen. Man har derfor brug for at benytte andre eksperter.

Én mulighed er at benytte forskere, men dels er antallet af forskere, der er trænede til at begå sig på tv eller udtale sig i radioen ikke stort, dels findes der nogle faglige grænser, som gør, at mange forskere oplever, at de bevæger sig uden for deres faglige kompetenceområde, når de skal vurdere dagens begivenheder.

Her er dagbladenes huskommentatorer et oplagt alternativ. Dels er de vandt til at foretage brede analyser, idet de ikke oplever faglighed indsnævret på samme måde som forskerne deres. Dels er de medievante.

Hos dagbladene arbejder man med en anden logik. Her betragtes de konkurrerende avisers kommentatorer som netop konkurrerende huseksperter. Pittelkow, Mogensen, Larsen og Engell er kendte personer, som „deres“ aviser benytter til at „brande“ sig med. Og der er ingen grund til at gøre reklame for konkurrenten ved at benyttes dennes kommentator. Som chefredaktør på Jyllands-Posten, Carsten Juste, udtrykker det: „Vi aviser kunne aldrig drømme om at lade de andre kommentere i vores avis. Aviserne har deres egne kommentatorer" (Journalisten 19.11.2007).

For det andet er det en udbredt opfattelse i den offentlige diskussion, at tænketanke i de senere år er kommet til at fylde mere i mediebilledet. Især efter at det er lykkedes den borgerlige tænketank Cepos succesfyldt at gøre opmærksom på dens publikationer, analyser, konferencer og møder - og i nogle tilfælde også sætte en politisk dagsorden.

Nogen central rolle spiller tænketankene dog langt fra i avisernes valgkampsdækning. De figurerer således kun i et meget begrænset omfang som ekspertkilde i de fire analyserede aviser.

Som nævnt er forskerne klart den oftest benyttede eksperttype i valgkampsartikler. Blandt disse kommer den alt overvejende del, 


\section{Tabel 5}

Samfundsvidenskabelige eksperter fordelt på forskningsområde, 1998 og 2007 under ét.

\begin{tabular}{|c|c|c|c|c|c|}
\hline & Politiken & $\begin{array}{l}\text { Jyllands- } \\
\text { Posten }\end{array}$ & $\begin{array}{c}\text { Berlingske } \\
\text { Tidende }\end{array}$ & $\begin{array}{l}\text { Ekstra } \\
\text { Bladet }\end{array}$ & I alt \\
\hline Politolog & 18 & 22 & 30 & 3 & 73 \\
\hline Økonom & 5 & 9 & 10 & 2 & 26 \\
\hline Jurist & 2 & 3 & 6 & & 11 \\
\hline Andet & 1 & 3 & 2 & & 6 \\
\hline
\end{tabular}

hele 94 procent, fra samfundsvidenskaberne. Sådan behøvede det ikke nødvendigvis at være. Mange af de emner, der er på den politiske dagsorden i en valgkamp, er samfundsforskere ikke nødvendigvis dem, der er bedst klædt på til at foretage en ekspertvurdering af. Samfundsforskere har således ikke meget at bidrage med, når det drejer sig om, hvor hurtigt kræftpatienter bør komme i behandling, den globale opvarmning eller dyrevelfærd.

Blandt de samfundsvidenskabelige eksperter er, som det fremgår af tabel 5 , tæt ved to tredjedele politologer, dvs. forskere i statskundskab, mens godt 20 procent er økonomer. Det er i og for sig ikke videre overraskende, da genstanden for politologernes forskning netop er politik, herunder valg og partier.

En, set fra et ligestillingssynspunkt, glædelig udvikling er en fordobling af valgkampsartikler med henvisning til kvindelige eksperter. Det skal imidlertid ses i det mindre opløftende perspektiv, at stigningens udgangspunkt har været meget lavt, nemlig blot 10 valgkampsartikler med henvisning til kvindelige eksperter i 1998. I 2007 henvises der fortsat kun til kvindelige eksperter i 16 procent af valgkampsartiklerne med ekspertreference.

\section{Hvad handler artiklerne om?}

Som nævnt skelnes der i kodningen af artikler indeholdende eksperthenvisninger mellem artikler, der handler om et politisk sagsindhold og artikler, der handler om den politiske proces (herunder tolkning af meningsmålinger). 


\section{Tabel 6}

Ekspertartikler omhandlende indhold og proces. Pct. af ekspertartikler

\begin{tabular}{lcc|cc}
\hline & \multicolumn{2}{c|}{1998} & \multicolumn{2}{c}{2007} \\
\hline & Proces & Indhold & Proces & Indhold \\
\hline Politiken & 36 & 68 & 43 & 61 \\
\hline Jyllands-Posten & 43 & 81 & 42 & 67 \\
\hline Berlingske Tidende & 96 & 40 & 82 & 42 \\
\hline Ekstra Bladet & 45 & 36 & & 100 \\
\hline I alt procent & 57 & 59 & 52 & 58 \\
\hline
\end{tabular}

For de fire analyserede aviser samlet set er der i valgkampene $\mathrm{i}$ 1998 og 2007 cirka lige mange ekspertartikler, der omhandler indhold og proces, sådan som det fremgår af tabel 6: I 1998 drejede det sig om henholdsvis 59 og 57 procent af ekspertartiklerne, i 2007 om henholdsvis 58 og 52 (bemærk, at samme artikel kan være kodet som omhandlende både politik og proces). Der er altså ikke noget, der tyder på, at aviserne i højere grad benytter eksperter til at analyse proces end indhold, eller at der i højere grad er fokus på proces i dag end for ti år siden (snarere er der et svagt fald $i$ andelen af ekspertartikler, der omhandler proces).

Der er dog også på dette punkt forskelle aviserne imellem. Hvis man ser bort fra Ekstra Bladet, der havde meget få ekspertartikler, tegner der sig det billede, at Berlingske Tidende bringer dobbelt så mange artikler med omtale af valgkampens proces som artikler med omtale af politiske emner. Det modsatte gør sig gældende for Jyllands-Postens og Politikens vedkommende.

De større dagblade bringer og kommenterer i dag løbende meningsmålinger i deres dækning af valgkampen. Man kunne derfor forestille sig, at aviserne i særlig grad henvender sig til eksperter - valgforskere - for at få en tolkning af eller kommentar til udviklinger i meningsmålinger. Det lader dog ikke til at være tilfældet: Der er et forsvindende lille antal ekspertartikler, der handler om meningsmålinger, i 1998 i alt ni og i 200713.

Den internationale litteratur har, som tidligere nævnt, påpeget, at der i dag er mere metaanalyse og -diskussion i nyhedsjournalistikken end tidligere. Netop her kunne man forestille sig, 
at det ville være oplagt for journalister at bede udenforstående eksperter om at rette blikket mod deres egen og deres kollegers valgkampsdækning. Men det er ikke tilfældet: Der er et forsvindende lille antal ekspertartikler med metadiskussion, i alt syv i 1998 og 13 i 2007.

\section{Særligt om samfundsvidenskabelige forskere og huskommentatorer}

Eftersom de samfundsvidenskabelige forskere udgør den langt overvejende del af de eksperter, der refereres til i valgkampsartikler, kan det være relevant at se, i hvilket omfang denne ekspertgruppe indgår i artikler, der beskæftiger sig med henholdsvis indhold og proces (tabel 7). Her viser det sig, at den næstestørste gruppe af samfundsvidenskabelige eksperter, nemlig økonomerne, i næsten alle tilfælde indgår i artikler, der beskæftiger sig med valgkampens indholdsmæssige aspekter, og i mindre end en tredjedel i artikler, der handler om valgkampens proces. Omvendt indgår politologerne i to tredjedel af tilfældene i artikler, der omhandler proces, og i lidt over en tredjedel af tilfældene indhold. Resultatet er ikke videre overraskende givet de to videnskabers genstandsfelt: Økonomi beskæftiger sig ikke videnskabeligt med den politiske proces, mens netop dette aspekt er i fokus i megen statskundskabsforskning.

Ser man på de artikler, som de fire analyserede avisers huskommentatorer (Mogensen, Pittelkow, Larsen og Engell) skrev i løbet af valgkampen 2007, omhandlede 96 procent af disse den politiske proces, mens 58 procent af artiklerne også berørte valgkampens emner. Med andre ord: Der er en klar overvægt af ar-

\section{Tabel 7}

Ekspertartikler med samfundsvidenskabelige forskere fordelt på type omhandlende indhold og proces, 1998 og 2007 under ét. Pct. af ekspertartikler med samfundsvidenskabelige forskere fordelt på type

\begin{tabular}{lcccc}
\hline & Politolog & Økonom & Jurist & Andet \\
\hline Proces & 68 & 31 & 45 & 67 \\
\hline Indhold & 37 & 96 & 64 & 67 \\
\hline
\end{tabular}


tikler, der fokuserer på proces, men samtidig berører over halvdelen af artiklerne også valgkampens indhold. I den henseende er det, blandt de øvrige eksperttyper, politologerne, der ligner de politiske kommentatorer mest.

Modsat den nævnte opfattelse i den offentlige debat, at de politiske kommentatorer fyldte meget i valgkampen i 2007 Uournalsten 19.11.2007), var det heller ikke tilfældet, hvis man ser på de artikler, som kommentatorerne selv skrev: Således skrev de fire huskommentarorer tilsammen 45 artikler i valgkampen - altså en halv procent af alle valgkampsartikler.

\section{Konklusion}

På baggrund af den foreliggende litteratur om emnet skulle man forvente en stigning i dagbladenes brug af eksperter i perioden 1998 til 2007. I absolutte tal er der da også for de fire aviser samlet set sket en stigning, men med forskelle aviserne imellem. Da der i perioden samtidig skete et drastisk fald i antallet af valgkampsartikler i de trykte aviser (med undtagelse af Berlingske Tidende), steg andelen af ekspertartikler (med undtagelse af Ekstra Bladet, hvis andel ekspertartikler er meget følsom over for udsving på grund af det absolutte antal artiklers yderst begrænsede størrelse).

Samlet set kan det konkluderes, at der er som forventet har fundet en stigning sted $i$ avisernes henvisning til ekspert i valgdækningen, om end stigningen i brugen af eksperter ikke er sket med samme hast som den generelle stigning i avisernes brug af eksperter op gennem 1990'erne. Det kan skyldes, at den store stigningstakt i journalisters brug af eksperter er aftaget. Det kan også skyldes, at der er tale om brug af eksperter i en speciel situation (valgkampe), og at der er tale om forholdsvis små tal, hvorfor man skal være varsom med at drage for vidtgående konklusioner.

Der er godt nok sket en fordobling i antallet af kvindelige eksperter i perioden 1998-2007, men alligevel må det konkluderes, at eksperter i medierne så godt som entydigt er mænd. Og forskere. Og ikke alene er de forskere: De er samfundsforskere. Og ikke alene samfundsforskere: De er politologer.

På baggrund af den internationale litteratur kunne man der- 
næst forvente, at der fra 1998 til 2007 ville være sket en markant forskydning fra ekspertartikler, der omhandlede valgkampens indhold, til artikler, der beskæftigede sig med den politiske proces, herunder om meningsmålinger og metadiskussioner om pressens egen dækning af valgkampen. Det viste sig imidlertid ikke at være tilfældet. Der var i både 1998 og 2007 cirka lige mange ekspertartikler, der refererede til valgkampens politiske indhold, dvs. at de nævnte de emner, som de politiske aktører bragte frem i valgkampen, som der var artikler, der beskæftigede sig med den politiske proces. Og der var ekstremt få artikler med metadiskussion.

\section{NOTER}

1. Sagt af Socialdemokraternes formand Helle Thorning-Schmidt under Dansk Journalistforbunds fagfestival, Nyborg, 6. november 2006.

2. Søgt i aviserne Berlingske Tidende, Jyllands-Posten, Politiken og Ekstra Bladet.

3. Det drejer sig om artikler af Peter Mogensen, Politiken, Thomas Larsen, Berlingske Tidende, Ralf Pittelkow, Jyllands-Posten, og Hans Engell, Ekstra Bladet.

\section{REFEREN CER}

Albæk, Erik, Peter Munk Christiansen \& Lise Togeby (2002). Eksperter $i$ medierne: Dagspressens brug af forskere 1961-20o1. Magtudredningen. Århus: Aarhus Universitetsforlag.

Bro, Peter, Rasmus Jønsson, Søren Schultz Jørgensen og Poul Anders Pedersen (2005). Mediernes Valgkamp: Et forsknings- og formidlingsprojekt om folketingsvalget 2005. Modinet/Mandag Morgen.

Esser, Frank, Carsten Reinemann \& David Fan (2001). "Spin Doctors in the United States, Great Britain, and Germany." Harvard International Journal of Press/Politics 6(1): 16-45.

Esser, Frank \& Paul D’Angelo (2006). "Framing the Press and Publicity Process in US, British, and German General Election Campaigns - A 
Comparative Study of Metacoverage." Harvard International Journal of Press/Politics, 11 (3), pp. 44-66

Patterson, Thomas E. 1994. Out of Order. New York: Vintage Books. 


\section{English Abstracts}

Experts in election news coverage: Process or substance?

ERIK ALB AEK, CHRISTIAN ELMELUND-PRAESTEKAR, DAVID NICOLAS HOPMANN \& ROBERT KLEMMENSEN

Reference to experts in the Danish print press has exploded during the last decades. This article investigates how journalists refer to experts during an election campaign. Two general election campaigns are analysed: 1998 and 2007. In absolute numbers there is an overall increase for the four newspapers surveyed, but with individual differences. As the number of election campaign articles dropped dramatically in the same period, the share of expert articles rose. Contrary to international debates on increased process journalism, in both 1998 and 2007 an equal number of articles referred to the election campaign's political content (i.e. they mentioned the topics promoted by the political actors during the campaign) and to the political process. 